


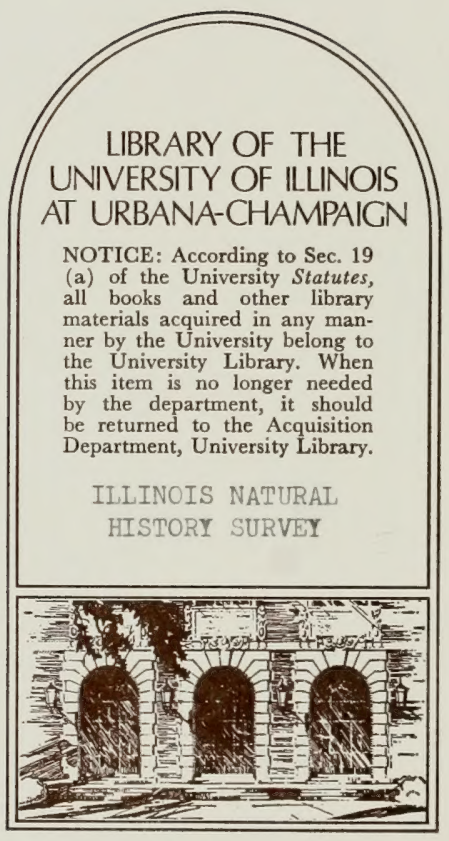






\section{The Production and Growth of $\mathrm{F}_{1}$ Hybrid Crappie}

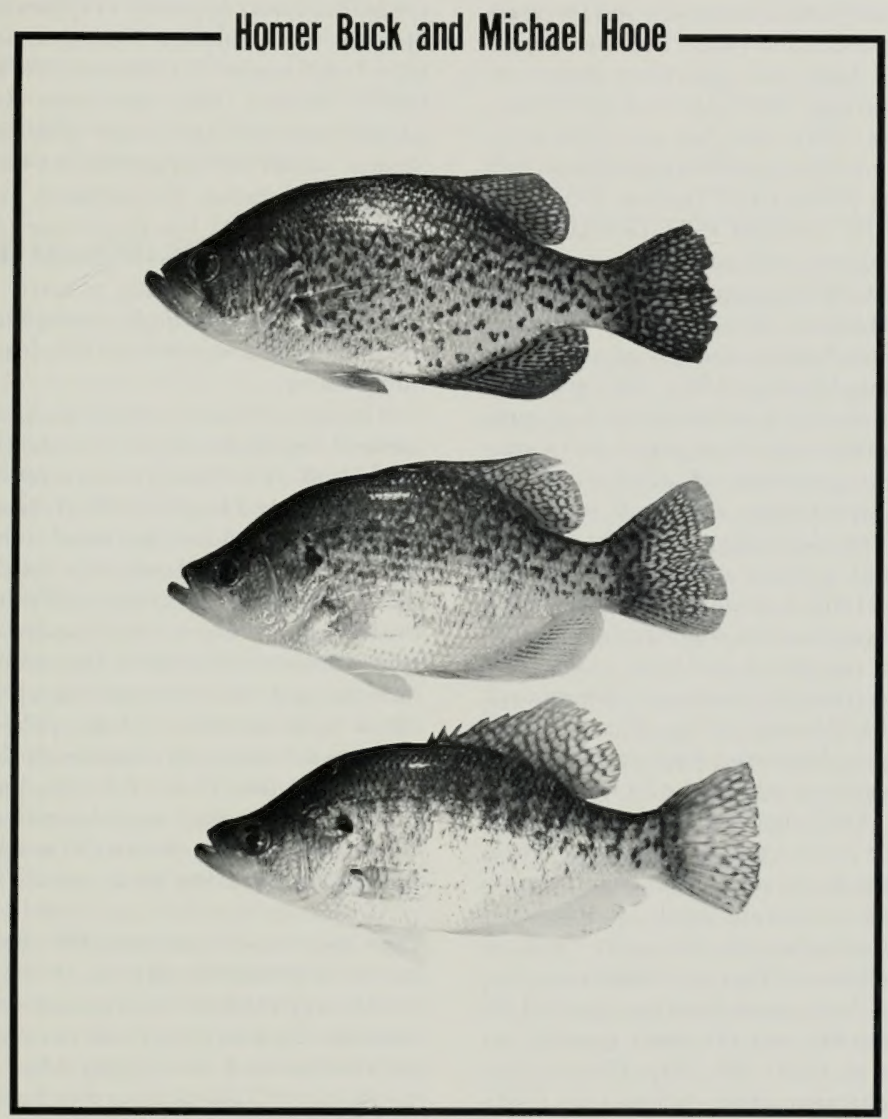

Illinois Natural History Survey

Champaign Illinois - February 1986

State of Illinois

Department of Energy and Natural Resources

Natural History Division 


\section{THE PRODUCTION AND GROWTH OF THE $F_{1}$ HYBRID CRAPPIE}

\section{Homer Buck and Michael Hooe}

The white crappie (Pomoxis annularis) and the black crappie ( $P$. nigromaculatus) are two of the most important sport fishes in lakes and reservoirs within the continental USA (Davison 1953; Hall et al. 1954; Morgan 1954; Goodson 1966), but they are difficult to manage. Problems arise through overpopulation, with consequent stunting (Clark 1952; Davison 1953; Hall et al. 1954; Cross 1967; Bennett 1971; George Lewis, personal communication) and competition with other fishes (Bennett 1944, 1971; Swingle 1952; McConnell and Gerdes 1964; Hackney 1975). Crappies may limit largemouth bass populations through predation on small bass (Swingle and Swingle 1967). The problems are more common among white than black crappie because white crappie are more abundant and widely distributed. White crappie normally are not included in stocking recommendations for small impoundments in southeastern states (George Lewis, personal communication), and in many areas their stocking is discouraged (Cross 1967; Lopinot 1972; Gabelhouse undated, 1984). Management recommendations in IIlinois now exclude crappies from farm ponds, and many biologists favor their elimination in all impoundments smaller than 100 hectares (Peter Paladino, personal communication). Following their own investigations and an exhaustive review of the literature, Rutledge and Barron (1972) believed that stunted year classes might best be prevented by suppressing reproduction with chemicals or water level manipulation and by mechanically removing age- 0 crappie. In a symposium on crappie management at the 1982 annual meeting of the Midwest Fish and Wildlife Conference in Des Moines, Iowa, participants recognized the small crappie syndrome and discussed possible remedies (O'Brien et al. 1984; Hill 1984; Ellison 1984; Gabelhouse 1984; Mosher 1984; Willis et al. 1984). Current management practices frequently involve introducing threadfin shad (Dorosoma petenense) to in-

This paper is published by authority of the State of Illinois and is a contribution from the Aquatic Biology Section of the Illinois Natural History Survey, where Dr. Homer Buck is an Aquatic Biologist and Michael Hooe is a Junior Professional Scientist.

Two on more outside referees recommend each manuscript submitred for publication in the Biological Notes series before it is accepted. crease the food supply for crappies (Heidinger 1977; Mitzner 1984; Mosher 1984) but other approaches have been made. Gabelhouse (1984) reviewed data which showed that predation on crappies by largemouth bass produced desirable-size crappies. Similar results were reported in a Colorado reservoir through predation by northern pike (Esox lucius) (Willis et al. 1984), but earlier use of such predators had only limited success (Rutledge and Barron 1972). In Missouri, where fishing pressure and exploitation rates for crappie are high, management involves regulating the harvest (Michael Colvin, personal communication).

The use of hybrid crappie may provide an alternate method for increasing the numbers of desirable-size individuals. White and black crappies hybridize in nature (Bailey and Lagler 1938; Hubbs 1955; Trautman 1957; W. F. Childers, personal communication), but these hybrids have been used sparingly in management. Bennett and Childers (1972) reviewed 13 years of creel records from a pond stocked with smallmouth bass (Micropterus dolomieui), lake chubsuckers (Erimyzon succetta), and laboratory-produced $\mathrm{F}_{1}$ hybrid crappie (black male $\mathrm{x}$ white female). The annual yield of smallmouth bass was consistently high (average: 68 $\mathrm{kg} / \mathrm{ha}$ ) and that of hybrid crappies consistently low (average: $4.8 \mathrm{~kg} / \mathrm{ha}$ ) over the entire 13-year period. They attributed the absence of overpopulation by the hybrid crappie to low fry survival. The only additional published information on hybrid crappies describes their enzymatic or herooglobin characteristics (Manwell et al. 1963; Metcalf et al. 1972a, 1972b). The only known unpublished information on hybrid crappies consists of meristic data and sex ratios from three $F_{1}$ populations and one $F_{2}$ population examined by $W$. $F$. Childers. Childers observed that the $F_{2}$ generation exhibited the expected broad range of morphological characteristics, but that the $F_{1}$ hybrid had a strong physical resemblance to, and could be misidentified as, a black crappie. Because of this tendency to misidentify the $F_{1}$ hybrid, he believed that most crappies identified in the field as hybrids were of the $F_{2}$ or later generations, and that the several 3- to 5-pound crappies he had examined had all been hybrids (personal communication). 
Except for preliminary observations in spring 1982. most of the data reported here were generated in the first 2 years of an ongoing comprehensive evaluation of hybrid crappies as sport fish (Illinois Federal Aid Project F-42-R, I October 1982 through 31 March 1987). The principal field investigations and the laboratory production of crappie fry were conducted at the Sam A. Parr Fisheries Research Center, near Kinmundy, Illinois, a cooperative facility of the Illinois Natural History Survey and the Illinois Department of Conservation. Crappies were genetically identified by starch-gel electrophoresis in laboratories of the IIlinois Natural History Survey, Champaign.

\section{MATERIALS AND METHODS}

Adult black and white crappies were collected in spring of 1983 and 1984 by electrofishing and trap netting in Illinois reservoirs. White crappie were collected from Forbes Lake in Marion County, and black crappies from Dawson Lake in McClean County, Ridge Lake in Coles County, and Schuy-Rush Lake in Schuyler County. Both white and black crappies were collected from Rend Lake in Jefferson County and Shelbyville Lake in Shelby County.

Half-sibling hybrid and pure stock crappie fry were produced in the laboratory by stripping eggs from a female and fertilizing half with milt from a black crappie and half with milt from a white crappie. Each group of eggs was dispersed over the bottom of a glass baking dish. Some dishes were placed under continuously flowing water $\left(22-24{ }^{\circ} \mathrm{C}\right)$ and others were held static in water at room temperature (approximately $24^{\circ} \mathrm{C}$ ) until hatching. Water was changed four times daily in all static dishes. Both hatching procedures were successful.

In both 1983 and 1984, first-year growth potentials of the $F_{1}$ hybrid were compared with those of the parent species by isolating fry of each reciprocal cross with fry of both parent species. In each combination of three genetic stocks, the hybrids were half-siblings to one of the pure species (Table 1). The reciprocal hybrids were not evaluated in the same ponds because they could not be marked when stocked as fry or later separated by appearance or by enzyme analysis. Approximately 48 hours prior to stocking, each pond was treated with a mixture of diesel fuel and motor oil to control predaceous insects.

The experimental ponds were drained in early October of 1983 and 1984 , and the three genetic stocks in each population were identified by enzyme analysis. If fewer than 200 crappies were recovered, all were analyzed; otherwise subsamples of approximately 200 fish were randomly selected for analysis. Each crappie
Table 1.-Total numbers and parentage (male $x$ female) of free-swimming crappie fry produced in the laboratory and stocked in 0.4-ha ponds in spring 1983 and 1984

\begin{tabular}{|c|c|c|c|c|c|}
\hline \multirow[b]{2}{*}{ Year } & \multirow[b]{2}{*}{ Pond } & \multicolumn{2}{|c|}{ Half-sibling } & \multicolumn{2}{|c|}{ Half-sibling } \\
\hline & & $\begin{array}{c}\text { Blackx } \\
\text { Black } \\
\end{array}$ & $\begin{array}{c}\text { Whitex } \\
\text { Black }\end{array}$ & $\begin{array}{l}\text { Blackx } \\
\text { White }\end{array}$ & $\begin{array}{c}\text { Whitex } \\
\text { White }\end{array}$ \\
\hline \multirow[t]{4}{*}{1983} & 4 & 425 & - & 475 & 475 \\
\hline & 7 & 400 & - & 420 & 380 \\
\hline & 8 & 380 & 480 & - & 400 \\
\hline & 9 & 250 & 200 & - & 400 \\
\hline \multirow[t]{2}{*}{1984} & 4 & 600 & - & 600 & 596 \\
\hline & 7 & 600 & 600 & - & 600 \\
\hline
\end{tabular}

to be analyzed was numbered, and sex, total length, and weight were determined. Each fish was tentatively identified by appearance as either a white, black, or hybrid crappie; numbers of dorsal spines were then recorded. Survival rates of each genetic stock of age- 0 , laboratory-spawned crappies were projected on the basis of the frequency with which each occurred in the subsamples subjected to enzyme analysis.

The potential for natural production of $F_{1}$ hybrids was tested by stocking mature adult crappies of mixed species in four ponds (two for each reciprocal cross) in each year from 1982 through 1984 (Table 2). Adult crappies stocked in each pond were matched by size; the range in mean length for the various populations was 18.9-24.7 cm. Each pond was drained 3-5 months following stocking. Numbers of adult and age-0 crappies were recorded and representative subsamples of age- 0 crappies were collected, frozen, transported to the fish genetics laboratory at Champaign, and held at $-20^{\circ} \mathrm{C}$ until analyzed.

The genetic identities of all crappie brood stocks and their progenies were established by enzyme analysis. Tissue extracts (white skeletal muscle) were prepared and subjected to vertical starch-gel electrophoresis and histochemical staining as described in Philipp et al. (1979). Stock was identified by determining the genotype at four enzyme loci that show fixed allelic differences between the species, Gpi-A, Gpi-B, Pgm-A, and Mdh-A (unpublished results).

\section{RESULTS AND DISCUSSION}

\section{Production}

Adequate numbers of fry of both reciprocal crosses and of both pure stocks were produced in the laboratory. Hatching rates of fertilized eggs were not recorded, but the successful production of large broods of healthy fry of all four stocks suggested that all had high viabilities. 
Table 2.- Numbers and sex of adult crappies stocked in natural reproduction ponds in spring and numbers of age-0 crappies recovered in fall draining censuses.

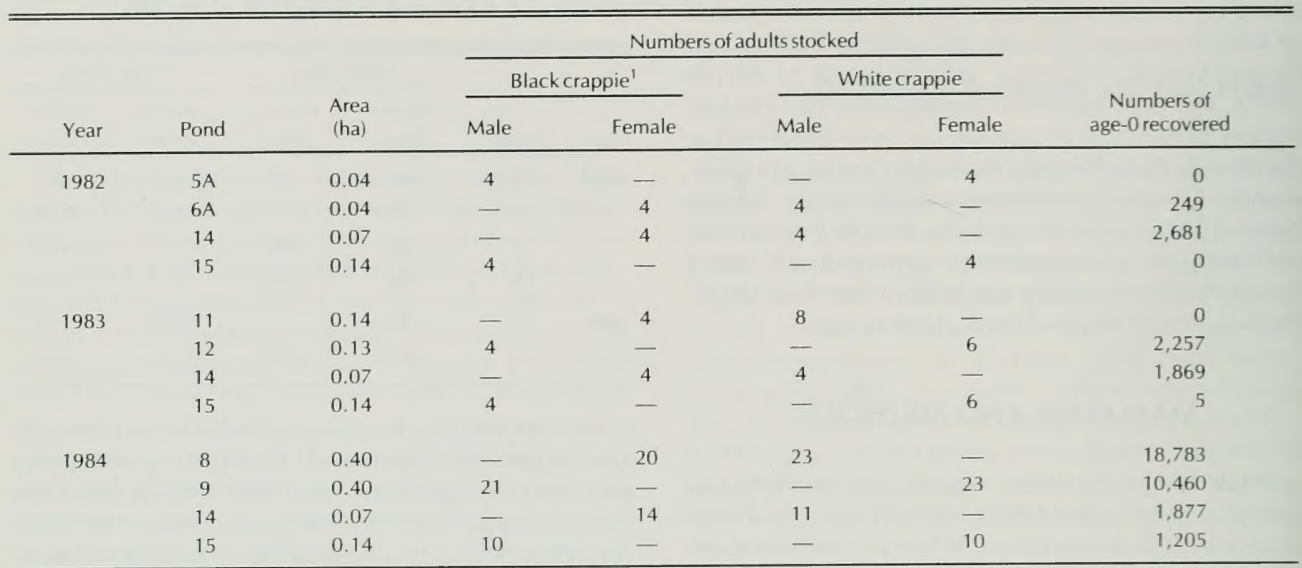

'Male crappies stocked in pond 12 in 1983 included one $F_{1}$ hybrid misidentified as a black crappie.

The natural production of hybrids by stocking males of one species with females of the other was also successful. Substantial numbers of age- 0 hybrids were recovered from five of six natural hybridization ponds that had been stocked with white males and black females (Table 2).

Age-0 crappies were recovered from four of six ponds that supposedly had been stocked with black males and white females (Table 2). Age-0 crappies from three of these ponds were identified as $F_{1}$ hybrids, but those from the fourth pond proved to be back-crossed individuals. The fall census of this pond yielded three adult males, one adult female, and 2,257 age- 0 crappies. Because the age- 0 fish did not appear typical of $F_{1}$ hybrids, all four adults and 205 young were subjected to enzyme analysis. The analysis revealed that one male breeder was an $F_{1}$ hybrid and that the entire sample of 205 age- 0 fish from this pond were the result of a back-cross between the $F_{1}$ hybrid male and a white crappie female. The $F_{1}$ breeder that had been mistaken for a male black crappie was collected in 1982 from either Lake Shelbyville or Schuy-Rush Lake.

The failure to recover $F_{1}$ hybrids from one pond in 1982 may have been due to pre-spawning mortality of all female breeders, because none were recovered in the fall. The second failure in 1982 could have been due to a combination of low water level and excessive turbidities (as high as 212 JTU). The recovery of only five hybrids from one pond in 1983 could have been related to predation of crappie eggs and larvae by an unusual abundance of crayfish observed during the pond census.

\section{Survival}

Survival rates of laboratory-produced, age-0 crappies through their first growing seasons varied greatly among populations (Table 3). The uniformly higher rates of survival in 1984 may have been due to a change in stocking procedures; in 1983 free-swimming fry were released into ponds directly from tubs, but in 1984 they were submerged in the ponds in Mason jars having screened openings from which they could escape at will.

Survival rates (Table 3 ) were derived in two ways. For ponds 4 and 9 in 1983, where total numbers of age- 0 crappies recovered were less than 200 (173 and 29 ), all were identified by enzyme analysis. Data presented for all other populations are based on the frequency with which each genetic stock occurred in the random sample of 200 fish selected for analysis and are subject to sampling error. Sampling error probably contributed to the projected survival rate of $100 \%$ for hybrid crappies in pond 8 in 1983 (Table 3). For the five populations for which more than 100 fish were recovered, Table 3 revealed a number of relationships:

1. Among half-siblings produced from black crappie eggs (ponds 8 in 1983 and 7 in 1984), survival of both the hybrids and black crappie was uniformly high $(>83 \%)$, compared with 51 and $32 \%$ for unrelated white crappies in the same ponds.

2. Among half-siblings produced from white crappie eggs, survival rates of the hybrids were consistently and significantly higher than those of their half-sibling white crappie. 
Table 3.- Parentage (male $x$ female) and percent survival of age-0 crappies produced in the laboratory, stocked in 0.4 -ha ponds in spring, and recovered in fall censuses in 1983 and 1984. Actual numbers recovered are shown in parentheses.

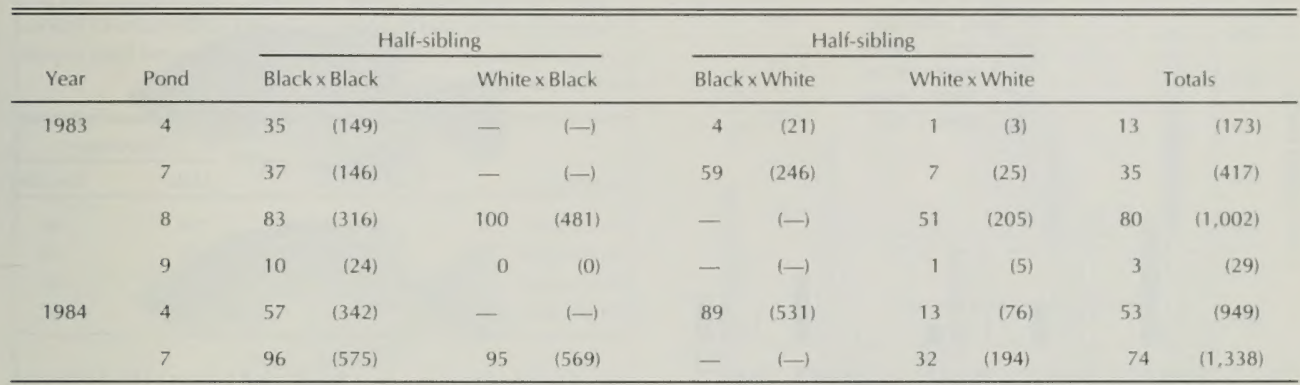

3. Mean survival rates for all populations of black and $F_{1}$ hybrid crappies were similar (59 and 53\%, respectively) and more than three times that for white crappie $(17.5 \%)$.

Rates of handling mortality among the laboratoryproduced crappies also were observed during draining censuses. Following selections of random samples for enzyme analysis, the remaining fish were separated by genetic stock. Many of these fish died or became severely debilitated during the sorting process, the great majority of which were white crappie. Both black and $F_{1}$ hybrid crappies were more tolerant of handling than white crappie. Harper (1938) also observed that black crappie withstood handling much better than white crappie.

\section{Growth and Condition}

First-year survival of age- 0 crappies was adequate to provide growth data in five of six populations. At the end of the first growing season, $F_{1}$ hybrids in all five populations were significantly longer and heavier $(\mathrm{P}<0.005)$ than either parent species that shared the same environment (Table 4, Figures 1 and 2).

The black crappie and both $\mathrm{F}_{1}$ hybrid crappies had higher mean condition factors $\left(\mathrm{K}_{\mathrm{TL}}\right)$ than did the white crappie in all ponds; mean condition factors of black crappie were equal or superior to those of either $\mathrm{F}_{\mathrm{I}}$ hybrid in all but one pond (Table 4). The only exception occurred in pond 4 in 1983, where the white male $x$ black female $F_{1}$ hybrids were in better condition than black crappie.

Table 4.-Parentage (male $x$ female), sample size $(\mathrm{N})$ and mean total lengths $(\mathrm{mm})$, weights $(\mathrm{g})$, and condition $\left(\mathrm{K}_{\mathrm{TL}}\right)$ of age-0 crappie spawned in the laboratory and censused in October 1983 and 1984. Half-sibling crappies in each pond are marked with asterisks. Standard deviations are in parentheses. B = black crappie: $\mathbf{W}=$ white crappie.

\begin{tabular}{|c|c|c|c|c|c|c|c|c|c|}
\hline \multirow{2}{*}{$\frac{\text { Year }}{1983}$} & \multirow{2}{*}{$\frac{\text { Pond }}{4}$} & \multirow{2}{*}{$\frac{\text { Parentage }}{\mathrm{B} \times \mathrm{B}}$} & \multirow{2}{*}{$\frac{N}{146}$} & \multicolumn{2}{|c|}{ Total length } & \multicolumn{2}{|c|}{ Weight } & \multicolumn{2}{|c|}{$\mathbf{K}_{\mathrm{TI}}$} \\
\hline & & & & 124 & (6.99) & 26.9 & (4.91) & 1.40 & $(0.04)$ \\
\hline & & $\mathrm{B} \times \mathrm{W}^{*}$ & 21 & 165 & $(17.05)$ & 70.4 & (23.09) & 1.51 & $(0.10)$ \\
\hline & & $W \times W^{*}$ & 3 & 119 & $(4.36)$ & 23.5 & (5.89) & 1.38 & $(0.21)$ \\
\hline & 7 & $\mathrm{~B} \times \mathrm{B}$ & 71 & 109 & $(5.08)$ & 17.5 & $(2.58)$ & 1.35 & $(0.11)$ \\
\hline & & $\mathrm{B} \times \mathrm{W}^{*}$ & 118 & 138 & $(5.75)$ & 35.7 & (4.62) & 1.35 & $(0.08)$ \\
\hline & 8 & $\mathrm{~B} \times \mathrm{B}^{*}$ & 63 & 104 & $(3.86)$ & 15.6 & (1.27) & 1.39 & $(0.07)$ \\
\hline & & $\mathrm{W} \times \mathrm{B}^{*}$ & 96 & 120 & $(3.80)$ & 21.6 & $(1.86)$ & 1.25 & $(0.06)$ \\
\hline & & $w \times w$ & 41 & 118 & $(4.60)$ & 17.8 & $(1.75)$ & 1.10 & $(0.05)$ \\
\hline \multirow[t]{3}{*}{1984} & 4 & $\mathrm{~B} \times \mathrm{B}$ & 72 & 114 & $(5.23)$ & 20.8 & $(2.76)$ & 1.41 & $(0.07)$ \\
\hline & & $B \times W^{*}$ & 112 & 142 & $(10.89)$ & 39.0 & (13.53) & 1.34 & $(0.08)$ \\
\hline & & $W \times W$ & 29 & 119 & $(3.15)$ & 18.1 & (1.33) & 1.06 & $(0.04)$ \\
\hline
\end{tabular}




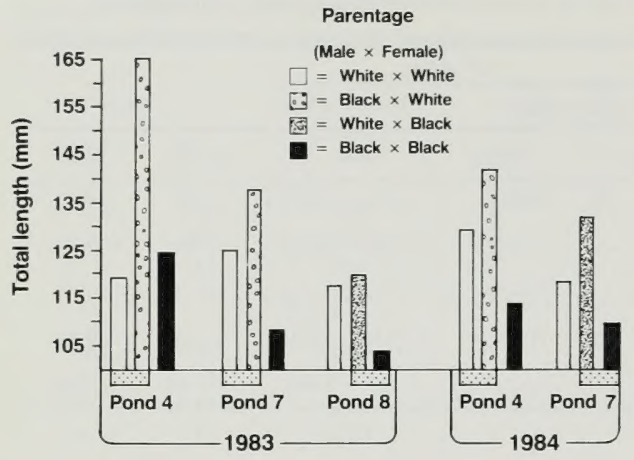

Fig. 1. Mean total lengths for four stocks of age-0 crappies censused in October 1983 and 1984. Half-siblings in each population are indicated by connecting bars at bases of columns.

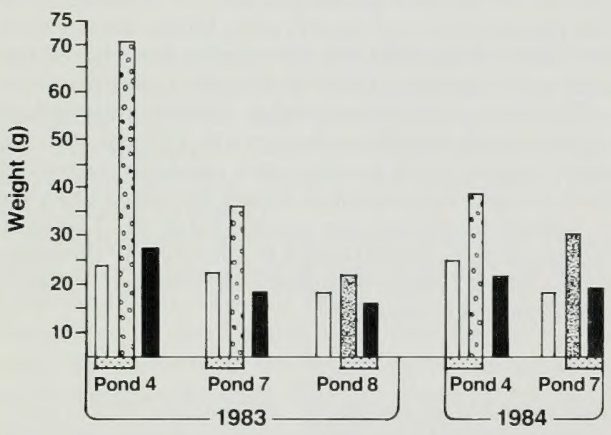

Fig. 2. Mean weights for four stocks of age-0 crappies censused in October 1983 and 1984. Half-siblings in each population are indicated by connecting bars at base of columns.

\section{Sex Ratios}

Schneberger (1972) stated that hybrid crappies produced in nature grew fast and were predominantly males but he provided no supporting data. Unpublished data from Childers (personal communication) showed equal sex ratios in two samples of 25 fish each and in one of 100 fish from three separate populations of laboratory-produced $F_{1}$ hybrids. He also found equal numbers of males and females in a sample of $100 \mathrm{~F}_{2}$ hybrids spawned in a pond. In the present study, the sexes were approximately equal in both reciprocal hybrids and in black crappie for laboratoryproduced fish, but females outnumbered males in white crappie (Table 5). Hansen (1951) found males predominated in natural populations of age- 0 and
Table 5.-Parentage (male $x$ female), total number, and percentage of males and females in pooled collections of laboratory-spawned age-0 and age- 1 crappies recovered from experimental ponds in fall censuses.

\begin{tabular}{lccc}
\hline \hline & & \multicolumn{2}{c}{ Percentage } \\
\cline { 3 - 4 } Parentage & Total number & Male & Female \\
\hline Black $\times$ black & 321 & 54 & 46 \\
White $\times$ black & 371 & 44 & 56 \\
Black $\times$ white & 211 & 53 & 47 \\
White $\times$ white & 125 & 38 & 62 \\
\hline
\end{tabular}

age- 1 white crappie, but Buck and Cross (1951) found the sexes were equal in a large sample of white crappies that represented several year classes.

\section{Morphology}

The genetic identities of crappies of unknown parentage were established by enzyme analysis, which permitted an evaluation of the identifications tentatively assigned when the samples were collected. Identifications assigned solely on appearance were $65 \%$ correct in 1983 but better than $96 \%$ accurate in 1984 . This improved rate of accuracy verifies that morphological differences between the $F_{1}$ hybrids and their parents can be recognized. As shown in Figure 3 , distinctions can be made on the basis of pigmentation and body conformation, but the differences are subtle and difficult to describe. Only one of the two reciprocal hybrids is pictured in Figure 3 because they were indistinguishable and both closely resembled the black crappie parent. All misidentified black and white crappies were mistaken for hybrids, and all but two misidentified hybrids were mistaken for black crappie.

Although identifications of mixed stocks were made prior to counting dorsal spines, the spine counts would have been of limited benefit due to a high degree of overlap in counts among the four genetic stocks (Figure 4). There was less variation in the number of dorsal spines for $F_{1}$ hybrids than there was for pure stocks; seven spines occurred on 91 and $92 \%$ of hybrids, whereas approximately equal percentages of white crappie had either 6 or 7 spines and similar percentages of black crappie had either 7 or 8 spines. Spine counts of $F_{1}$ hybrids in this study agreed with those of an $F_{1}$ population analyzed in $1958(83 \%$ with 7 spines; Buck, unpublished data) and with two $F_{1}$ populations analyzed in 1966 (80 and $96 \%$ with 7 spines; Childers, personal communication). Counts of 7 or 8 spines on black crappie were similar to those reported in the literature, but counts of 6 or 7 spines for white crappie were higher than the 5 or 6 spine count common in the literature (Trautman 1957; 


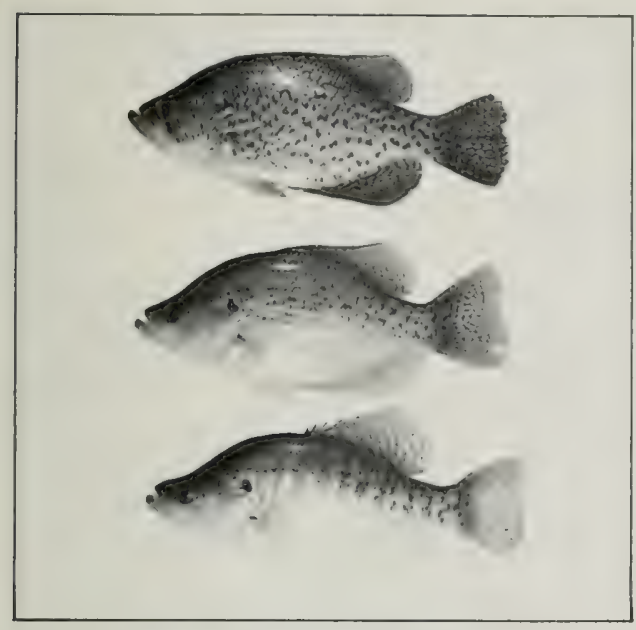

Fig. 3. $F_{1}$ hybrid crappie between black crappie above and white crappie below. All fish were age- 1 with total lengths of $24-25 \mathrm{~cm}$.

Cross 1967; Pflieger 1975; Smith 1979). Our higher count may have been due to the presence of a very small anterior spine on many white crappie, which was visible only when probed for with a pointer. The "extra" spine on our laboratory-produced white crappie may be a physical aberration related to either the in zitro method of fersilization or to the ammatural laboratory environment in which the zygotes developed.

\section{CONCLUSIONS}

1. Both reciprocal crosses of white crappie with black crappie can be produced by in ritro fertilization techniques and, in this investigation, exhibited viabilities similar to those of their half-sibling pure stocks.

2. Both interspecific $F_{1}$ hybrid crappies can be produced in ponds by isolating males of one species with females of the other.

3. Both interspecific F, hybrid crappies grew significantly faster than either parent in their first growing season.

1. The two reciprocal $\mathrm{F}_{1}$ lypbrid orappies were indistinguishable in appearance and resembled the black crappie paren more closely than the white crappic.

5. Suble differences in pigmentation and body conformation can be used os separatle the f, hybrid from the parent species.

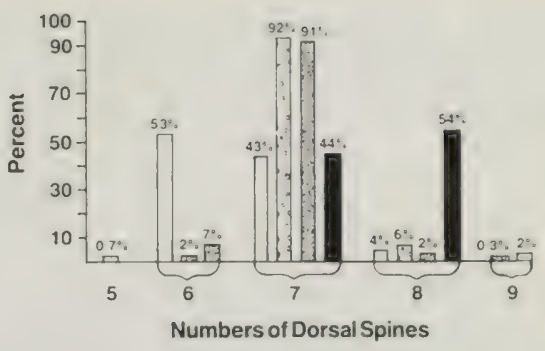

Fig. 4. Percentages of populations of four stocks of age-0 crappies having various numbers of dorsal spines.

6. Both the $\mathrm{F}$, hybrid and the black crappie were much more tolerant of handling than was the white crappie.

7. Populations of both $F$, hybrids spawned in the laboratory had nearly equal sex ratios.

8 . It was shown that at male $F_{1}$ hybrid crappie could back-cross with a white crappie female. Other backcrosses were not tested.

9. $F_{1}$ hybrid crappies are present in natural populations in Illinois.

\section{ACKNOWLEDGMENTS}

We wish to thank Larry R. Mitzner, of the lowat State Conservation Commission. and Michat $\mathrm{X}$. Colvin, of the Missouri Department of Conservation, for helpful reviews of the manuscript. We are alsograteful to Jana Waire, R. W. Larimore, David P'. Philipp, and Glen C. Satnderson, all of the Illinois Natural Histor Survey, for their constructive comments.

Principal funding of this study was through Federal Aid in Fish Restoration Project $\mathrm{F}-12-\mathrm{K}$ administered by the Illinois Department of Conservation. We are deeply indebted to the late Dr. W. F. Childers for his donation of umpublished data, for assistance in project development, and for supervising our intial laborat tory production of crappie fry. We also thank Dr. fohn Trancuilli for support and counsel and for the perusal of data collected jointly with Childers. D). David P. Philiph) was generous with counsel, assisted in the laboratory production of fry, and provided leadership and facilities for the electophoretis analyses that established the genetic identities of both the parent crappies and their progenies. We are indebed to feff koppleman and his assistants for comeluct. 
ing the electrophoretic analyses. Thanks are also due to Don Dufford, Bob Dunn, Ray Fisher, Buz Imboden, Steve Jenkins, and Gary Lutterbie of the Illinois Department of Conservation; to Ted Storck and Steve
Miller of the Illinois Natural History Surrey; and to Roy Heidinger of Southern Illinois University for exceptional cooperation in the collection of white and black crappies from wild populations.

\section{LITERATURE CITED}

Bailey, R. M., and K. F. Lagler. [938. An analysis of hybridization in a population of stunted sunfishes in New York. Papers of the Michigan Academy of Science, Arts and Letters 23:577-606.

Bennett, G. W. 1944. The effects of species combinations on fish production. Transactions of the 9th North American Wildlife Conference, p. 184-190.

1971. Management of lakes and ponds. 2nd ed. Van Nostrand Reinhold Company, New York. 375 p.

, and W. F. Childers, 1972. Thirteen-year yield of smallmouth bass from a gravel pit pond. Journal of Wildlife Management 36:1249-1253.

Buck, H., and F. Cross. 1951. Early limnological and fish population conditions of Canton Reservoir, Oklahoma, and fishery management recommendations. Report to the Oklahoma Fish and Game Council, The Research Foundation, Oklahoma Agricultural and Mechanical College, Stillwater. $174 \mathrm{p}$.

Clark, M. 1952. Kentucky's farm fish pond program. Journal of Wildlife Management 16:262-266.

Cross, F. B. 1967. Handbook of fishes of Kansas. Miscellaneous Publication No. 45. Museum of Natural History, University of Kansas, Lawrence. 357 p.

Davison, V. E. 1953. Homemade fishing; bass and trout waters you can build yourself. The Stackpole Co. Harrisburg, PA 205 p.

Ellison, D. G. 1984. Trophic dynamics of a Nebraska black crappie and white crappie population. North American Journal of Fisheries Management 4:355-364.

Gablehouse, D. W.. Jr. 1984. An assessment of crappie stocks in small midwestern private impoundments. North American Journal of Fisheries Management 4:371-384.

Undated. Managing Kansas ponds for fish and wildlife. Kansas Fish and Came Commission. 8 p.

Goodson, L. F. Jr. 1966. Crappie. Pages 312-332 in A. Calhoun, ed. Inland fisheries management. California Department of Fish and Game.

Hackney, P. A. 1975. Bass populations in ponds and community lakes. Pages 131-139 in R. H. Stroud and H. Clepper, eds. Blach bass biology and management. Sport Fishing Institute, Washington, D.C:

Hall, G. E., R. M. Jenkins, and J. C. Finnell. 1954. The influence of environmental conditions upon the growth of white crappie and black crappie in Oklahoma waters. Oklahoma Fisheries Research Laboratory Report No. 40.

Hansen, D. F. 1951. Biology of the white crappie in Illinois. Illinois Natural History Survey Bulletin 25:211-265.

Harper, D. C. 1938. Crappie and calico bass culure in Texas. Progressive Fish-Culturist 38:12-14.

Heidinger, R. C. 1977. Potential of the threadfin shad as a forage fish in midwestern power cooling reservoirs. Transactions of the Illinois State Academy of Science 70:15-25.

Hill, K. R. 1984. Correlation of total and "angler-acceptable" crappie standing stoxks with lake basin slopes and siltation indexes. North American Journal of Fisheries Managenent 4:350-354.

Hubbs, C. L. 1955. Hybridization between fish species in nature. Systematic Zoology 4:1-20.

Lopinot, A. C. 1972 . Pond fish and fishing in Illinois. 2nd ed. Fishery Bulletin No. 5, Illinois Department of Conservation, Springfield. $72 \mathrm{p}$.
Manwell, C., C. M. A. Baker, and W. Childers. 1963. The genetics of hemoglobin in hybrids. I. A molecule basis for hybrid vigor. Comparative Biochemistry and Physiology 10:103-120.

Mc Connell, W. J., and J. H. Gerdes. 1964. Threadfin shad, Dorosoma petenense, as food of yearling centrarchids. California Fish and Game 50:170-175

Meicalf, R. A., G. S. Whit, and W. F. Childers. 1972a. Inheritance of esterases in the white crappie (Pomoxis annularis), black crappie ( $P$. nigromaculatus), and their $\mathrm{F}_{1}$ and $\mathrm{F}_{2}$ interspecific hybricis. Animal Blood Group and Biochemical Genetics 3:19-33. and R. L. Metcalf. 1972b. A comparative analysis of the tissue esterases of the white crappie (Pomoxis annularis Rafinesque) and black crappie (Pomoxis nigromamaculatus sic LeSueur) by electrophoresis and selective inhibitors. Comparative Biochemistry and Physiology $41 \mathrm{~B}: 27-38$.

Mitzner, L. 1984. Crappie management: problems and solutions. North American Journal of Fisheries Management 4:339-340.

Morgan, G. 1). 1954. The life history of the white crappie (Pomoxis anmularis) of Buckeye Lake, Ohio. Joumal of the Scientific Laboratories Denison University 43:113-144.

Mosher, T. D. 1984. Responses of white crappie and black crappie (6) threadfin shad introductions in a lake containing gizzard shad. North American Journal of Fisheries Management 4:365370 .

O'Brien, W. J., B. Loveless, and D. Wright. 1984. Feeding ecology of young white crappie in a Kansas reservoir. North American Journal of Fisheries Management 4:3\$1-349.

Pflieger, W. L. 1975. The fishes of Missouri. Missouri Department of Conservation. $343 \mathrm{p}$.

Philipp, 1). P. W. F. Childers, and G. S. Whitt. 1979. Evolution of patterns of differential gene expression: a comparison of the temporal and spatial patterns of isozyme locus expression in two closely related fish species (northern largemouth bass. Microplenus salmoides salmoides, and smallmouth bass, Mficropternu dolomieui). Journal of Experimental Zoology 210:473-487.

Rutledge, W. P., and J. C. Barron. 1972. The effects of the removal of stunted white crappie, Pomoxis anmularis Rafinesque, on the remaining crappic population of Meridian State Park Lake, Bosque County, Texas. Texas Parks and Wildlife Department Technical Bulletin No. 12.

Schneberger, E. 1972. The black crappie: its life history, ccolog? and management. Wisconsin Department of Natural Resources Publication 243-72. $16 \mathrm{p}$.

Smith, P. 1Y. 1979. The fishes of Hlinois. University of 1 llinois Press. Urbana. $31.4 \mathrm{p}$.

Swingle, H. S. 1952. Farm pond investigations in Alabama. Journal of Wildlife Management 16:243-249

and W. E. Swingle. 1967. Problems in dynamics of tish populations in reservoirs. Pages $224-243$ in Reserwoir lisher! tesounces symposum. Southern Division. Anerican Fisheries Soxiety

Irautman. M. B. 1957. The tishes of Ohio. Oho State Universits Press, Columbus. $683 \mathrm{p}$.

Willis, 1). W.. J. F. Smeltzer, and S. A. Flichinger. 1984. Charateristics of a crappic population in an unfished small impoundmem (ontaining northern pike. North American Journal of tish . Management. 4:385-389. 





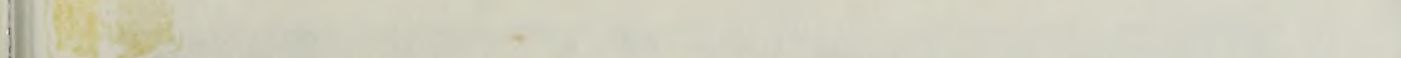


